\title{
DANA PENSIUN DALAM PERSPEKTIF EKONOMI ISLAM
}

\author{
M. Johari \\ Fakultas Syariah Institut Agama Islam Qamarul Huda
}

\begin{abstract}
Abstrak
Sistem pendanaan pensiun memungkinkan terbentuknya suatu akumulasi dana yang dibutuhkan untuk memelihara kesinambungan penghasilan peserta program pada hari tua. Islam mengajarkan umatnya untuk mempersiapkan hari tua sebaik mungkin. Pendirian dana pensiun dapat dipandang sebagai pengamalan terhadap sebagian ajaran ekonomi Islam tentang penghormatan terhadap mereka yang menjalani hari tua. Pemanfaatan dana pensiun sebagai tunjangan dihari tua merupakan suatu hal yang tepat dan sangat dibutuhkan oleh seluruh karyawan baik negeri maupun swasta. Dengan adanya dana pensiun, diharapkan dapat membantu kesejahteraan sosial ekonomi masyarakat Indonesia pada umumnya dan umat Islam pada khususnya. Pemanfaatan dana pensiun harus sesuai dengan hukum ekonomi Islam (figh muamalah).

Kata Kunci; Karyawan, Dana Pensiun, Hari Tua
\end{abstract}

\section{A. PENDAHULUAN}

Dalam rangka pelaksanaan pembangunan nasional yang pada hakikatnya merupakan pembangunan manusia Indonesia seutuhnya dan pembangunan seluruh masyarakat Indonesia berdasarkan pancasila dan UUD 1945, maka upaya untuk mewujudkan kehidupan yang layak bagi seluruh rakyat Indonesia merupakan kewajiban konstitusional yangharus dilakukansecaraberencana, bertahap dan berkesinambungan.

Sejalan dengan itu, upaya memelihara kesinambungan penghasilan pada hari tua perlu mendapat perhatian dan penanganan yang lebih berdaya guna dan berhasil guna. Dalam hubungan ini di masyarakat telah berkembang suatu bentuk tabungan masyarakat yang semakin banyak dikenal oleh para karyawan yakni dana pensiun. Bentuk tabungan ini memiliki ciri sebagai tabungan jangka panjang untuk dinikmati hasilnya setelah karyawan yang bersangkutan pensiun. Penyelenggaraan dilakukan dalam suatu program, yakni program pensiun, yang mengupayakan menfaat pensiun bagi pesertanya melalui suatu system pemupukan dana yang lazim disebut system pendanaan.

System pendanaan suatu program pensiun memungkinkan terbentuknya suatu akumulasi dana yang dibutuhkan untuk memelihara kesinambungan penghasilan peserta programpadaharitua. Keyakinan akan adanya kesinambungan penghasilan 
menimbulkan ketentraman kerja, sehingga akan meningkatkan motivasi kerja karyawan yang merupakan iklim yang kondusif bagi peningkatan produktivitas. Dalam dimensi yang lebih luas, akumulasi dana yang terhimpun dari penyelenggaraan program pensiun merupakan salah satu sumber dana yang diperlukan untuk memelihara dan meningkatkan pembangunan nasional yang berlandaskan kemampuan sendiri. Hal ini sejalan dengan salah satu arah dan kebijakan pembangunan jangka panjang, yakni peningkatan dan pengembangan sumber-sumber dana pembangunan yang berasal dari dalam negeri secara optimal, baik dari pemerintah maupun dari masyarakat.

Islamjuga mengajarkan umatnya untuk mempersiapkan hari tua sebaik mungkin. Hal tersebut telah dijelaskan dalam Al Qur'an maupun Al Hadits, yang mana hari esok merupakan suatu hal yang tidak pasti, tidak ada seorang pun yang mengetahui bagaimana kehidupan yang akan datang, apakah sejahtera ataukah sebaliknya, sengsara? Karenanya dana pensiun merupakan suatu program yang sangat penting sebagai upaya kesejahteraan di hari tua.

\section{B. SEKILAS DEFINISI DANA PENSIUN}

Dana pensiun adalah suatu badan hukum yang mengelola dan menjalankan program yang menjanjikan manfaat pensiun bagi pesertanya. Badan hukum ini secara rutin mengumpulkan iuran pensiun dari pegawai yang menjadi pesertanya selanjutnya pembayaran kembali dilakukan pada saat pegawai sudah tidak bekerja lagi. ${ }^{1}$ Dari penjelasan tersebut menunjukkan bahwa dana pensiun merupakan sebuah lembaga, dan lembaga tersebut berbadan hukum serta bertugas menjalankan program untuk memberikan manfaat pensiun kepada para pesertanya. Sebagai sebuah lembaga, dana pensiun memiliki beberapa fungsi diantaranya yakni sebagai asuransi (takafful), yang terlihat dalam hal peserta meninggal dunia atau mengalami cacat sebelum usia pensiun, sebagai tabungan, karena dana yang dihimpun dari iuran peserta dan iuran pemberi kerja, sebagai pensiun yang akan dibayarkan kepada peserta yang pensiun atau yang berhak menerimanya (janda, anak atau orang yang ditunjuk) secara berkala setelah memasuki usia pension. ${ }^{2}$

Terkait dengan kelembagaan dana pensiun, terdapat dua jenis yakni: pertama, Dana Pensiun Pemberi Kerja (DPPK) yakni dana pensiun yang dibentuk oleh orang atau badan yang mempekerjakan karyawan, selaku pendiri dan untuk menyelenggarakan program pension, manfaat pasti atau program pensiun iuran pasti, bagi kepentingan sebagian atau seluruh karyawan sebagai peserta, dan yang menimbulkan kewajiban terhadap pemberi kerja. Kedua, yakni Dana Pensiun Lembaga Keuangan (DPLK) yakni dana pensiun yang dibentuk oleh

'Subagyo, dkk. Bank dan Lembaga Keuangan Lain. (Yogyakarta: STIE YKPN, 2008), hal.168

'Syamsul Anwar, Studi Hukum Islam Kontemporer (Jakarta: RM. Books, 2007), hal.212 
bank atau perusahaan asuransi jiwa untuk menyelenggarakan program pensiun iuran pasti bagi perorangan, baik karyawan maupun pekerja mandiri, yang terpisah dari dana pensiun pemberi kerja bagi karyawan bank atau perusahaan asuransi jiwa yang bersangkutan.

Dari penjelasan di atas dapat disimpulkan perbedaan dari DPPK dan DPLK yakni dana pensiun pemberi kerja dibentuk oleh pemberi kerja, sedangkan dana pensiun lembaga keuangan didirikan oleh bank atau perusahaan asuransi jiwa dan terpisah dari bank atau perusahaan asuransi yang bersangkutan serta dari dana pensiun pemberi kerja yang mungkin didirikan oleh bank atau oleh perusahaan asuransi untuk karyawannya. Dalam pelaksanaannya dana pensiun memiliki tiga jenis program sebagaimana disebutkan dalam UU No. 11 Tahun 1992 yakni program iuran pensiun pasti (Defined Contribution Plan), program pensiun manfaat pasti (Defined Benefit Plan) dan program pensiun berdasarkan keuntungan (Profit Sharing Pensiun Plan).

Program iuran pensiun pasti adalah program pensiun yang mana iurannya telah ditetapkan dalam peraturan dana pensiun dan seluruh iuran serta hasil pengembangnnya dibukukan pada rekening masingmasing peserta sebagai manfaat pensiun, dan besar iuran yang akan dibayar ditentukan secara pasti, misalnya $2 \%$ dari gaji pokok, namun manfaat pensiun yang akan diterima tidak dapat ditentukan, tergantung pada lamanya peserta membayar iuran. Biasanya program pensiun iuran pasti ini diikuti oleh para pekerja mandiri bukan karyawan perusahaan, seperti konsultan, pengacara, pengusaha mandiri, atau dokter yang tidak bekerja pada suatu lembaga. Program pensiun ini diselenggarakan oleh DPLK dan DPPK.

Sedangkan pensiun manfaat pasti adalah program pensiun yang manfaatnya ditetapkan oleh peraturan dana pensiun atau program pensiun lain yang bukan merupakan program pensiun iuran pasti. Penentuan manfaat didasarkan pada formula tertentu yang ditetapkan dalam peraturan dana pensiun. Misalnya bagaimana dalam kasus dana pensiun Muhammadiyah $\quad(2,5 \% \quad \mathrm{X}$ masa kerja $\mathrm{X}$ penghasilan dasar pensiun). Program ini hanya diselenggarakan oleh DPPK (Dana Pensiun Pemberi Kerja). Program pensiun berdasarkan keuntungan adalah program pensiun iuran pasti dengan iuran hanya dari pemberi kerja yang didasarkan pada rumus yang dikaitkan dengan keuntungan pemberi kerja. Kekayaan dana pensiun bersumber dari iuran pemberi kerja, iuran peserta, iuran investasi dan pengalihan dari dana pensiun lain.

Syarat-syarat menjadi peserta dana pensiun adalah setiap pegawai yang telah diangkat sebagai pegawai tetap sesuai dengan peraturan pemberi kerja dan telah berusia 18 tahun atau telah menikah. Kepesertaan dana pensiun dimulai sejak pegawai terdaftar sebagai peserta dan berakhir pada saat pegawai meninggal dunia 
atau pensiun atau berhenti bekerja dan telah mengalihkannya ke dana pensiun lain. Seorang peserta tidak dapat mengundurkan diri atau menuntut haknya dari dana pensiun apabila masih memenuhi syarat kepesertaan.

Terdapat beberapa macam manfaat dana pensiun yang diperuntukkan bagi peserta sesuai dengan keadaan masing-masing yakni: (1) manfaat pensiun normal yang diperuntukkan bagi peserta yang berhenti bekerja dan telah mencapai usia pensiun normal (usia 55 tahun bagi tenaga non edukatif dan usia 60 tahun bagi tenaga edukatif); (2) manfaat pensiun dipercepat yang diperuntukkan bagi peserta yang berhenti bekerja dan telah mencapai usia pensiun dipercepat (sekurangkurangnya 10 tahun sebelum usia pensiun normal), namun belum memasuki usia pensiun normal; (3) manfaat pensiun cacat yang diperuntukkan bagi peserta yang berhenti bekerja karena cacat; (4) pensiun ditunda yang diperuntukkan bagi peserta yang berhenti bekerja dan belum mencapai usia pensiun dipercepat dan telah memiliki masa kepesertaan sekurang-kurangnya 3 tahun; (5) iuran peserta sendiri plus bunga yang layak dan dibayarkan sekaligus, diperuntukkan bagi peserta yang berhenti bekerja dan belum mencapai usia pensiun dipercepat, namun telah memiliki masa kepesertaan kurang dari 3 tahun.

Jika peserta meninggal dunia, janda atau duda berhak atas manfaat pensiun janda atau duda. Jika janda atau duda tidak ada atau meninggal dunia atau kawin lagi, manfaat pensiun dibayarkan kepada anak. Manfaat pensiun anak wajib dibayarkan sampai anak mencapai usia 21 tahun. Pembayaran pensiun anak dimaksud diteruskan sampai anak mencapai usia 25 tahun dengan ketentuan: anak tidak memiliki penghasilan sendiri dan belum menikah serta masih sekolah atau kuliah.

\section{SEKILAS DANA PENSIUN DALAM SEJARAH EKONOMI ISLAM}

"Tidaklah termasuk golongan ummatku orang yang tidak mneghormati orang yang berusia lanjut dan tidak menyayangi anakanak" (HR. Ahmad). Dari hadis tersebut dapat disimpulkan bahwa, selaku muslim meski menghormati orang tua dengan cara dan bentuk apapun. Terkait dengan dana pensiun yakni setiap perusahaan meski memperhatikan kesejahteraan karyawannya yang sudah tidak produktif atau yang telah berusia lanjut. Mereka berhak mendapat apa yang menjadi haknya, yakni berupa tunjangan hari tua agar mereka terus dapat bertahan hidup meski sudah tidak bekerja lagi.

Dengan demikian, pendirian dana pensiun dapat dipandang sebagai pengamalan terhadap sebagian ajaran sosial ekonomi Islam tentang penghormatan terhadap mereka yang menjalani hari tua. Hal semacam ini, secara historis bukan suatu yang asing dalam sejarah Islam. Pada zaman khulafaurrosyidin, para khilafah 
menetapkan system tunjangan. ${ }^{3}$ Meskipun merupakan tunjangan hari tua, system tersebut menggambarkan ajaran Islam yang menekankan penyediaan rasa aman dan jaminan ekonomi bagi warga masyarakat. Seperti disebutkan dalam salah satu hadis Rasulullah Saw, dalam doa Beliau memohon agar terhindar dari hari tua yang jelek. Doa tersebut yang artinya sebagai berikut "Ya Tuhan aku mohon kepada-Mu akan kebaikan yang terdapat pada malam ini dan kebaikan pada saat-saat sesudahnya dan aku berlindung kepada-Mu dari kejahatan yang ada pada malam ini dan kejahatan pada saat-saat sedudahnya. Ya Tuhan aku berlindung kepada-Mu dari kemalasan dan hari tua yang jelek. Ya Tuhan aku berlindung kepada-Mu dari siksaan di dalam neraka dan siksaan di dalam kubur" (HR. Muslim). Pada zaman khalifah Abu Bakar ash Shiddiq tunjangan itu disamaratakan. Akan tetapi pada zaman khalifah Umar bin Khattab tunjangan dibedakan diantara berbagai penerima sesuai dengan jasajasa yang telah diberikan penerima terhadap Islam. ${ }^{4}$
${ }^{3}$ Lihat Veithzal Rivai. Manajemen Sumber Daya Manusia untuk Perusahaan: dari Teori ke Praktek. (Jakarta: Raja Grafindo Persada, 2006). Lihat juga Ani Faujiah.” Ijaroh: Sebuah Upaya untuk Mencari Keadilan Antara Karyawan dan Majikan”. Jurnal Ekosiana. Jurnal Ekonomi Syariah STAI An Najah Surabaya. Volume 1 Nomor 1 Maret 2014, hal. 51-54

${ }^{4}$ Syamsul Anwar, Studi...hal.220-222

\section{DANAPENSIUNBAGIPESERTA MENINGGAL DUNIA DALAM EKONOMI ISLAM}

Didalam Al Qur'an dan Al Hadits terdapat beberapa rujukan tentang hari tua, yang keseluruhannya terlihat sebagai hari yang dapat menimbulkan keperihatinan jika tidak dipersiapkan sebelumnya. Seperti yang telah dijelaskan di atas mengenai manfaat pensiun bagi orang yang meninggal dunia. Maka manfaat pensiunnya diberikan kepada janda atau duda, jika janda atau duda tidak ada maka diberikan kepada anaknya, jika anaknya tidak ada maka diberikan kepada orang yang ditunjuk. Begitu pula dalam ekonomi Islam, apabila seseorang meninggal dunia dan meninggalkan harta kekayaan maka harta kekayaannya dan seluruh hal-hal meteriil yang ditinggalkannya beralih demi hukum dan secara otomatis menjadi hak ahli warisnya, sesuai dengan ketentuan Rasulullah Saw yang artinya "Dari Abu Hurairah r.a dari Nabi Saw (diriwayatkan bahwa) Beliau Saw berkata, barang siapa meninggalkan harta kekayaan maka kekayaan itu adalah untuk para ahli warisnya" (HR. Jamaah ahli hadis, seperti Bukhari, Muslim dan para penyusun kitab-kitab sunah).

Dari penjelasan di atas tampak bahwa pemberian manfaat dana pensiun meninggal dunia sesuai dengan kaidah hukum Islam tantang waris. Namun terdapat beberapa hal yang harus diperhatikan, seperti apakah pemanfaatan dana pensiun peserta meninggal dunia sesuai 
dengan hukum waris? Jika dalam hukum waris dijelaskan dengan rinci bagian-bagiannya apakah begitu halnya dalam manfaat dana pensiun orang yang meninggal dunia? Namun berdasarkan hadist Nabi Saw di atas bahwa pada pokoknya harta peninggalan seseorang diwariskan menurut ketentuan hukum waris syariah kepada para ahli waris yang berhak. Namun dalam Islam juga terdapat lembaga wasiat, yang mana seseorang dapat menunjuk orang yang akan menerima kekayaannya setelah meninggal. ${ }^{5}$

Sebagaimana makna pewarisan, yakni proses pemindahan harta yang dimiliki seseorang yang sudah meninggal kepada pihak penerima yang jumlah, ukuran dan bagian yang diterimanya telah ditentukan dalam mekanismewarisan. ${ }^{6}$ Jadijika sipewaris telah menulis wasiat maka harta yang ditinggalkannya menjadi hak yang diberi wasiat, namun jika si pewaris tidak menulis wasiat maka hartanya dibagikan sesuai dengan hukum waris. Namun ada ketentuan yang harus dipenuhi dalam penerimaan wasiat yakni: pertama, jumlah kekayaan yang diterima orang yang ditunjuk melalui wasiat tidak melebihi sepertiga jumlah seluruh kekayaannya. Kedua, orang yang ditunjuk bukan ahli waris yang berhak. Hal ini seperti ditegaskan dalam Q.S. An Nisa' ayat 12 yang artinya "Jika yang mewariskan tidak memiliki ayah atau anak, namun ada

${ }^{5}$ Ibid. hal. 224-225

${ }^{6}$ Muhammad Syahrur. Metodologi Fikih Ko temporer. (Yogyakarta: Elsaq Press, 2004), hal. 334 saudara laki-laki dan perempuan, masing-masing dari keduanya mendapat seperenam. Tetapi jika mereka lebih dari seorang, mereka berbagi dalam sepertiga, sesudah diselesaikannya wasiat dan hutang sehingga tidak ada seorangpun yang dirugikan, demikianlah ketentuan Allah, Allah maha mengetahui lagi maha penyantun".

Dalam PP No. 77 Tahun 1999 pasal 19 dan pasal 20 dijelaskan bahwa: Pasal 19 ayat (1) dalam hal peserta meninggal dunia, manfaat pensiun dibayarkan kepada janda atau duda atau anak; ayat (2) manfaat pensiun bagi janda atau duda dibayarkan seumur hidup; ayat (3) dalam hal tidak ada janda atau duda meninggal dunia, atau janda atau duda kawin lagi, manfaat pensiun dibayarkan kepada anak; ayat (4) manfaat pensiun kepada anak wajib dibayarkan sampai anak tersebut mencapai usia sekurang-kurangnya 21 (dua puluh satu) tahun. Selanjutnya pada pasal 20 ayat (1) dalam hal peserta meninggal duniadan tidak ada janda atau duda atau anak maka dana yang merupakan hak peserta dibayarkan kepada pihak yang ditunjuk oleh peserta; ayat (2) pembayaran sebagaimana dimaksud dalam ayat (1) dilakukan secara sekaligus. $^{7}$

Hal tersebut di atas bertentangan dengan ketentuan hukum ekonomi syariah (fiqh muamalah), karena menurut ketentuan hukum ekonomi syariah (fiqh muamalah) dana tersebut

${ }^{7}$ PP No.77 Tahun 1999 Tentang Dana Pe siun Lembaga Keuangan 
menjadi hak para ahli waris. Dana tersebut bisa menjadi hak milik orang yang ditunjuk jika memenuhi ketentuan tersebut di atas, seseorang peserta meninggal dunia boleh membuat wasiat apabila dana yang menjadi haknya itu tidak melebihi sepertiga kekayaannya, maka seluruh manfaat pensiun dapat diterima sebagai wasiat kepada orang yang ditunjuk. Akan tetapi jika dana (manfaat pensiun) melebihi dari sepertiga darijumlah seluruh kekayaan yang ditinggalkan peserta setelah dilunasi hutang dan kewajibannya, maka kelebihan itu tidak dapat diterima kepada pihak yang ditunjuk, melainkan harus dimasukkan kedalam kekayaan yang diwariskan kepada ahli waris. Atas dasar ini, maka pasal $20 \mathrm{di}$ atas harus diperrbaiki sesuai dengan ketentuan hukum ekonomi Islam (fiqh muamalah) bahwa seluruh kekayaan seseorang termasuk sisa dana miliknya dilembaga dana pensiun diwariskan kepada ahli waris.

Sekarang kita perhatikan pasal sebelumnya, yakni pasal 19 yang mana disebutkan hal peserta meninggal dunia, maka manfaat pensiun dibayarkan kepada janda atau duda seumur hidupnya dan jika janda atau duda itu meninggal atau menikah lagi maka dibayarkan kepada anak hingga mencapai umur 21 tahun. Hal tersebut dapat diterima dari segi hukum ekonomi syariah (figh muamalah), oleh karena tidak bertentangan dengan hukum kewarisan Islam. Sebagaimana ditegaskan dalam Q.S. An Nisa' ayat 9 yang artinya "Dan hendaklah takut kepada Allah orang-orang yang seandainya mereka meninggalkan dibelakang mereka anak-anak yang lemah, mereka khawatir terhadap kesejahteraan mereka"

Dengan demikian pembayaran manfaat pensiun kepada janda atau duda seumur hidupnya dan jika janda atau duda itu meninggal atau menikah lagi maka dibayarkan kepada anak itu tidak dipandang sebagai wasiat melainkan merupakan suatu tindakan hukum ekonomi syariah (fiqh muamalah) tersendiri yang merupakan kongkretisasi terhadap asas perlindungan masa depan keluarga yang ditinggalkan. ${ }^{8}$

\section{E. PENUTUP}

Dari pembahasan di atas dapat disimpulkanbahwaharituamerupakan suatu masa yang harus diperhatikan secara intensif, jika tidak demikian maka akan dapat menimbulkan kesengsaraaan dan tidak menikmati hari tua dengan bahagia. Selain itu penghormatan terhadap seseorang yang berusia lanjut juga selayaknya dilakukan, dan Islam mengajarkan hal tersebut.

Pemanfaatan dana pensiun sebagai tunjangan dihari tua merupakan suatu hal yang tepat dan sangat dibutuhkan oleh seluruh karyawan baik negeri maupun swasta. Dengan adanya dana pensiun, maka diharapkan dapat membantu kesejahteraan sosial masyarakat Indonesia pada umumnya dan umat Islam pada khususnya. Pemanfaatan

${ }^{8}$ Syamsul Anwar, Studi...hal.227 
dana pensiun harus sesuai dengan hukum ekonomi Islam (fiqh muamalah) dan hal tersebut telah terbukti pada hal pemanfaatan dana pensiun meninggal dunia, yang mana dana tersebut diberikan kepada janda atau

\section{DAFTAR PUSTAKA}

Ani Faujiah.” Ijaroh: Sebuah Upaya untuk Mencari Keadilan Antara Karyawan dan Majikan". Jurnal Ekosiana. Jurnal Ekonomi Syariah STAI An Najah Surabaya. Volume 1 Nomor 1 Maret 2014.

http://www.bapepam.go.id/dana pensiun/edukasi dp/istilah. $\underline{\text { htm }}$

http: / / www.fiskal.depkeu.go.id/ bapekki/klip/detailklip. asp?klipID $=\mathrm{N} 349346426$

http://www.taspen.com/files / uu 11 thn 1992 tentang dana pensiun.pdf

Muhammad Syahrur. Metodologi Fikih Kontemporer. Yogyakarta: Elsaq Press. 2004. duda, jika janda atau duda meninggal dunia atau menikah lagi maka harta tersebut diberikan kepada anaknya. Hal ini sesuai dengan hukum waris dalam Islam.

PP No.77 Tahun 1999 Tentang Dana Pensiun Lembaga Keuangan

Siagian, Sondang P. Manajemen Sumber Daya Manusia. Jakarta: Bumi Aksara. 2003.

Subagyo, dkk. Bank dan Lembaga Keuangan Lain. Yogyakarta: STIE YKPN. 2008.

Syamsul Anwar, Studi hukum Islam Kontemporer. Jakarta: RM. Books. 2007.

Veithzal Rivai. Manajemen Sumber Daya Manusia untuk Perusahaan: dari Teori ke Praktek. Jakarta: Raja Grafindo Persada, 2006. 